\title{
Qualitative Determination of Methane Gas at Selected Sites in Kampala City, Uganda
}

\author{
Mary Magdalein Nakibuuka ${ }^{1,2}$, Dean Tashobya ${ }^{1}$, Noble Banadda ${ }^{2}{ }_{*}$, Fildah Ayaa $^{2}$, Innocent Nhapi $^{3}$, \\ Umaru Garba Wali ${ }^{4}$ and Richard Kimwaga ${ }^{5}$ \\ ${ }^{1}$ Uganda National Bureau of Standards (UNBS), P.O. Box 6329, Kampala, Uganda \\ ${ }^{2}$ Makerere University, Department of Agricultural and Bio-Systems Engineering, P. O. Box 7062, Kampala, Uganda \\ ${ }^{3}$ Department of Civil Engineering, University of Zimbabwe, Box MP167, Mt. Pleasant, Harare, Zimbabwe \\ ${ }^{4}$ WREM Project, Faculty of Applied Science, National University of Rwanda, Box 117 Butare, Rwanda \\ ${ }^{5}$ Department of Water Resources Engineering, University of Dar-es-Salaam P. O. Box 35131, Dar-es-Salaam, Tanzania
}

\begin{abstract}
Solid Waste (WS) sorting at primary source, collection, transportation and disposal are a challenge in many cities in the developing world. Experiences from the developed world indicate that planning, education, enforcement and resources are needed to effectively manage SW. Poor SW management is responsible for many diseases especially in the developing world. Taking Kampala as a case study, with a population of 1.2 million people, SW is deposed off in public landfills, and open dumps near and/or burnt in residential areas. SW in landfills emit significant amounts of a potent greenhouse gas, methane. Studies from elsewhere have demonstrated that this contributes to the greenhouse effect and global warming. However, most of the developed methods to determine methane gas are expensive and requirement cumbersome sample preparation procedures. More often than not, such equipments are not present in many developing countries. As such data on methane gas emissions in Kampala city and Uganda as a whole are scarce and those that are available are models based on other country estimates A Gas chromatography equipped with a Flame Ionization Detector (GC-FID) method was used to make a qualitative study of methane gas generated from SW in Kampala City so as to inform the relevant decision makers on the need to take appropriate measures to reduce open environment methane emissions at dumping sites.
\end{abstract}

Keywords: Solid waste, landfills, methane gas, qualitative estimation, GC-FID, Kampala city.

\section{INTRODUCTION}

Uganda's population has continued to grow over a period of time. It increased from 9.5 million in 1969 to 24.2 million in 2002 at an average annual growth rate of 3.2 percent between 1991 and 2002. The projected 2010 mid-year population stood at 31.8 million. Kampala, the capital city of Uganda, has a population of 1.2 million people and the population has been increasing by $3.9 \%$ per annum [1]. The amount of solid waste has been increasing with the increasing population and changing socio-economic standards. Increasing urbanization and improving economic conditions are resulting into increased waste generation in developing countries.

The increasing amount of waste, along with changing waste management practices with a shift from open dumps to sanitary landfills, will result in higher methane emissions if the gas is not flared or recovered at landfills and other waste collection sites [2]. Landfills are currently the most common

*Address correspondence to this author at the Department of Agricultural and Bio-systems Engineering, Makerere University, P.O. Box 7062, Kampala-Uganda; Tel: +256 7740466 89; Email: banadda@agric.mak.ac.ug

1874-8295/12 option for final disposal of municipal solid waste in developing countries. Land filling is an economical and a readily available means of solid waste disposal. However, land filling requires careful selection of the site such that dumping does not result in significant adverse effects on public health or environment.

When landfills are not properly managed they pollute the air, surface and underground water. Leachate from landfills with high organics, if discharged into a river, increases its biochemical oxygen demand leading to low oxygen available to the existing living organisms.

Organic matter also contains plant nutrients, especially nitrogen and phosphorus, which when released into water, may cause eutrophication. Municipal solid waste (MSW) landfills are also recognized as one of the major sources of anthropogenic emissions generated from human activities.

In India, most of the solid wastes are disposed of by land filling in low-lying areas located in and around the urban centers resulting in generation of large quantities of biogas containing a sizeable proportion of methane. Waste landfills have been recognized as the large source of anthropogenic methane emission and an important contributor to global 
warming. Methane emission from landfill is estimated to account for $3-19 \%$ of the anthropogenic sources in the world. The estimation has been made from mere calculation using national statistics on waste generation. In many countries, especially the developing economies of the world, the available data on waste generation are not consistent, leading to a large uncertainty in the estimates [3].

Kampala City Council Authority (KCCA) has had conflicts with people living near its dumpsites. The conflicts stem from the bad odor, leachate and scattering of wastes from the dumping sites by wind and scavengers like Marabou storks. KCCA currently dumps some of the waste at Mpererwe landfill site located $12 \mathrm{~km}$ from Kampala city centre. Due to environmental pollution and increased conflicts with the local communities, several of the KCCA dumping sites have been closed [4]. This has also led to the careless disposal of garbage and solid waste at different sites in the city and its suburbs, this in addition to lack or poor waste management practices. Hence, there are many solid waste disposal sites scattered carelessly in and around Kampala city.

These may potentially produce high amounts of greenhouse gases being emitted which have not yet been evaluated and quantified by the National environmental authority. Quantification of the methane gas emission is important in order to evaluate measures for reductions of the methane gas emissions. International protocols have already been put into place by the United Nations to ensure quantification of methane emission from landfills. All methods given as a guide to estimate the emissions are based on models. Studies by Scharff and Jacobs [5] showed huge differences in the results and raised doubts about the accuracy of the models. The mass and rates of methane emissions depends on many factors that are difficult to quantify and these vary from site to site [6]. Direct measurement tools to qualitatively determine methane emissions are scarce and those that are available are models based on other country estimates. Currently, there are limited published studies done in Uganda to determine methane gas generated from solid waste disposed at open dumping sites due to lack of means and equipments to do so. Therefore, the objective of this study is to make a qualitative determination of methane gas from solid waste from selected sites in Kampala City using a gas chromatography equipped with a Flame Ionization Detector (GC-FID) method so as to inform the relevant decision makers on the need to take appropriate measures to reduce open environment methane emissions at dumping sites.

\section{MATERIALS AND METHODOLOGY}

The method used is relatively simple and inexpensive. Solid waste was collected from four disposal sites located in Namugongo and Kisaasi, two different suburbs in Kampala City. The solid waste was prepared and analyzed for methane gas using a Varian CP-3800 Gas chromatography (GC) equipped with a Flame Ionization Detector (FID). Sites 1 and 2 had no burning of the waste while sites 3 and 4 frequent burning of the waste was done. From each site, three samples from different points where taken and put into labeled airtight polythene garbage bags which were tightly sealed. The samples were immediately transported to the laboratory in coolers. The samples from sites 1 and 2 were homogenized together and analysed in triplicates A, B and C, and the samples form sites 3 and 4, as triplicates D, E and F. About $20 \mathrm{~g}$ from each bag were transferred into $250 \mathrm{ml}$ plastic bottles (digestor), $50 \mathrm{ml}$ of distilled water gently added and the bottle tightly capped. The samples were left to stand at room temperature and analyzed after 3 days of collection. Using disposable syringes the bottles were punctured at one point on top of the bottle, and the gas collected immediately using a GC injection syringe. Equal amounts of $3 \mu \mathrm{l}$ of the accumulated gas were taken for each of the samples. A blank was also injected and run along with the samples under the same conditions. The gas sample was identified qualitatively using the GC-FID detector [7]. The Gas Chromatography (GC) protocol was developed for the analysis of the samples. Samples were analyzed using a GC-FID (Varian-3800) detector. The column was WCOT fused silica $(50 \mathrm{~m} \mathrm{x}$ $0.25 \mathrm{mmID}$ ). Coating CP-SIL 8CB (5\% phenyl; 95\% dimethyl polysiloxane), D.F 0.12. The carrier and make up gas was high purity gas nitrogen at $1 \mathrm{ml} / \mathrm{min}$. The column oven was programmed at an initial temperature of $50^{\circ} \mathrm{C}$ held at 10 minutes, then $50^{\circ} \mathrm{C}$ to $200^{\circ} \mathrm{C}$ at a rate of $20^{\circ} \mathrm{C} / \mathrm{min}$. The oven was then held at $200^{\circ} \mathrm{C}$ for 10 minutes. Total run time was 27.5 minutes. The injector was set at $200^{\circ} \mathrm{C}$; split ratio of 100. The FID detector was set at $250^{\circ} \mathrm{C}$ at a range of 12 . The flow rate was set at $1 \mathrm{ml} / \mathrm{min}$. The methane gas peaks were noted to have retention times between 14.0 and 15.0 minutes. It suffices to note that pure methane gas was not available for comparison purposes.

\section{RESULTS AND DISCUSSION}

Results from the GC-FID method developed showed distinct variations in the chromatograms generated from the two sample types, that is, the composite sample containing organic matter and inorganic sample. The variation in the chromatogram peaks indicates the difference in the amount of methane gas generated from the solid waste, the difference in the composition of the solid waste sampled from different sites and solid waste management practices carried out at the different disposal site. There was no peak observed in the chromatogram for the blank injection (Fig. 1).

The high chromatogram peaks (Figs. 2, 3 and 4) where generated from the samples collected from landfill sites where no combustion or burning of the solid waste was carried out.

These samples contained more organic waste and comparatively low plastics and more biodegradable matter. The chromatogram peaks indicated high amounts of methane gas being generated from the waste. The amount and rate of methane production at a landfill depends of five key characteristics of the land-filled materials and the surrounding environment, these divided into physical and management practices [8]. Methane and other landfill gases from solid waste disposal sites are generated by degradation of biodegradable fractions and influenced by physio-chemical composition of the waste as well as environmental variables. The environmental variables include $\mathrm{pH}$, temperature, moisture, and availability of nutrients [9]. The most significant factor driving high amounts of methane generation is the quantity of 


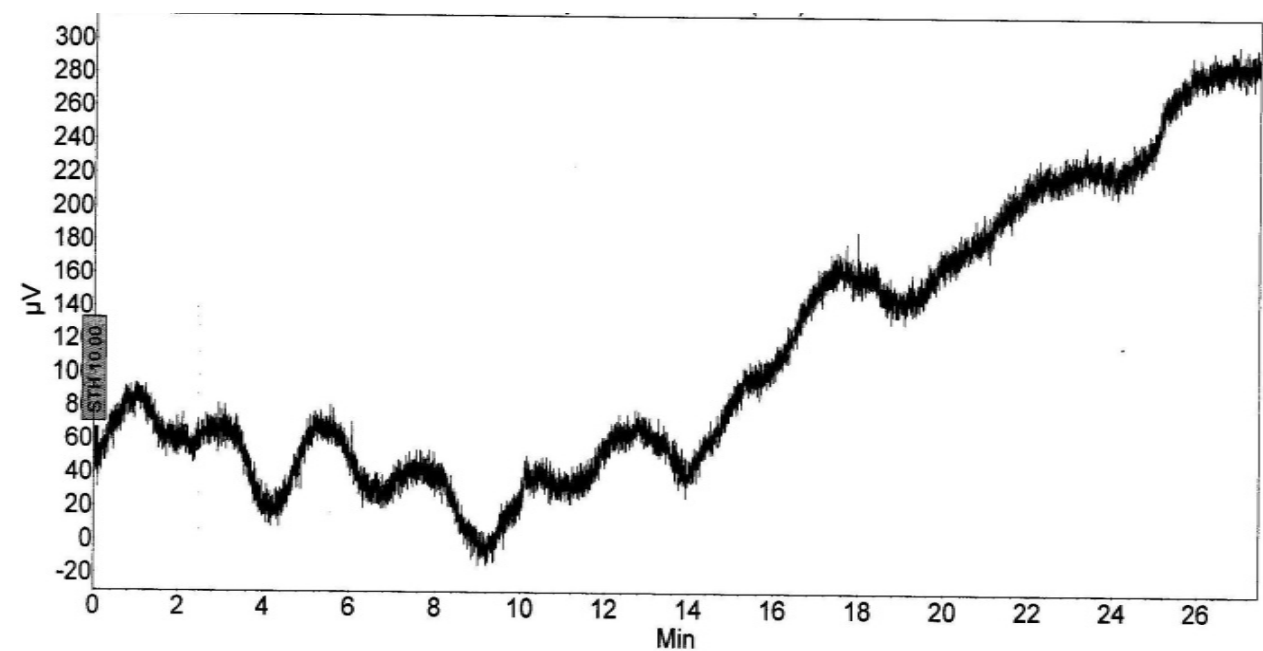

Fig. (1). Chromatograph generated on using air as a blank.

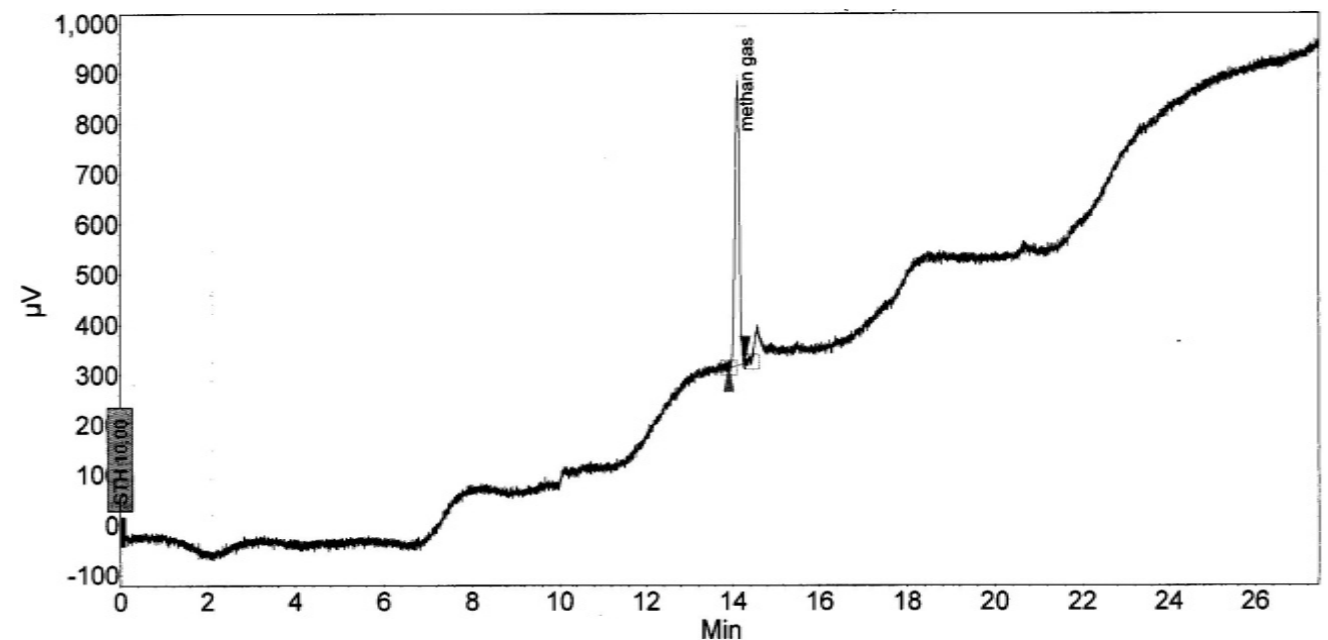

Fig. (2). Composite sample A for solid waste from site 1 and 2.

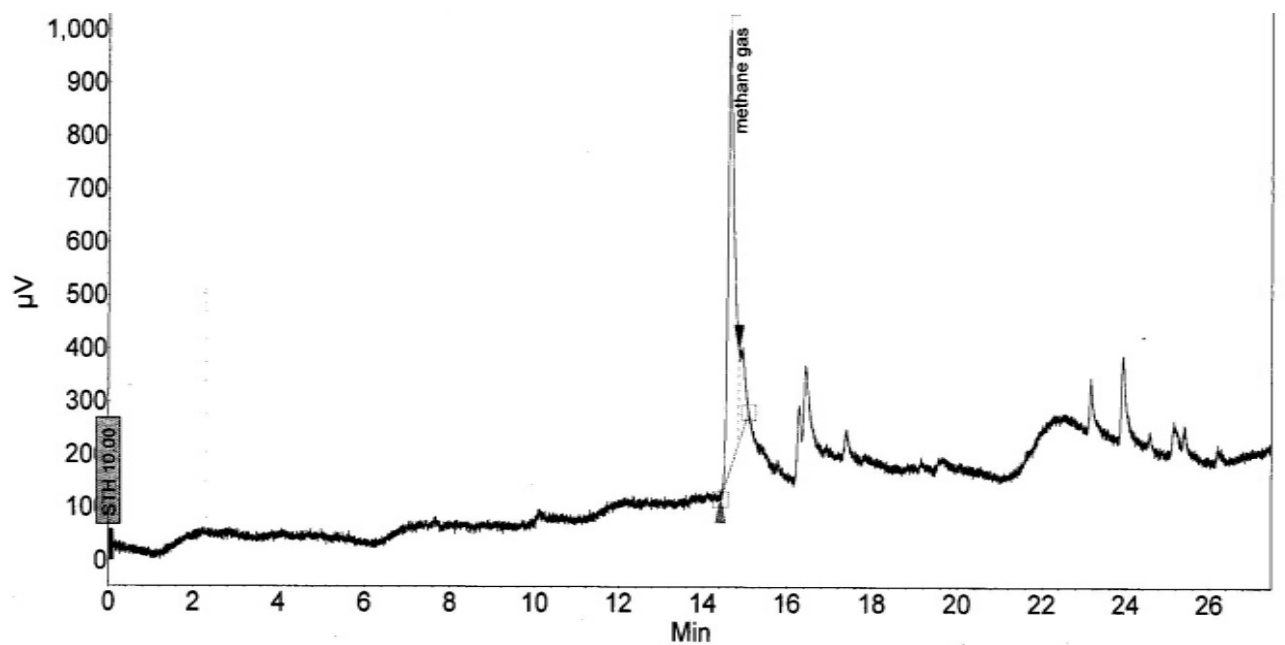

Fig. (3). Composite sample B for solid waste from site 1 and 2. 


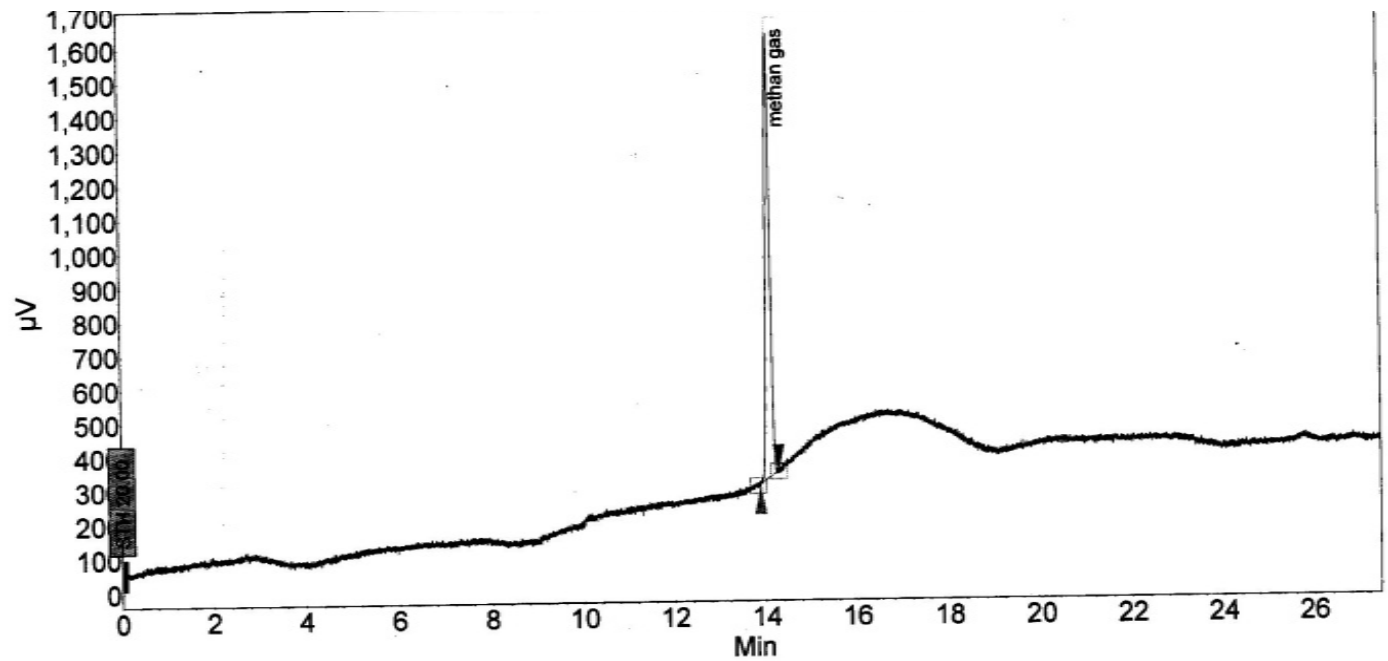

Fig. (4). Composite sample C for solid waste from site 1 and 2.

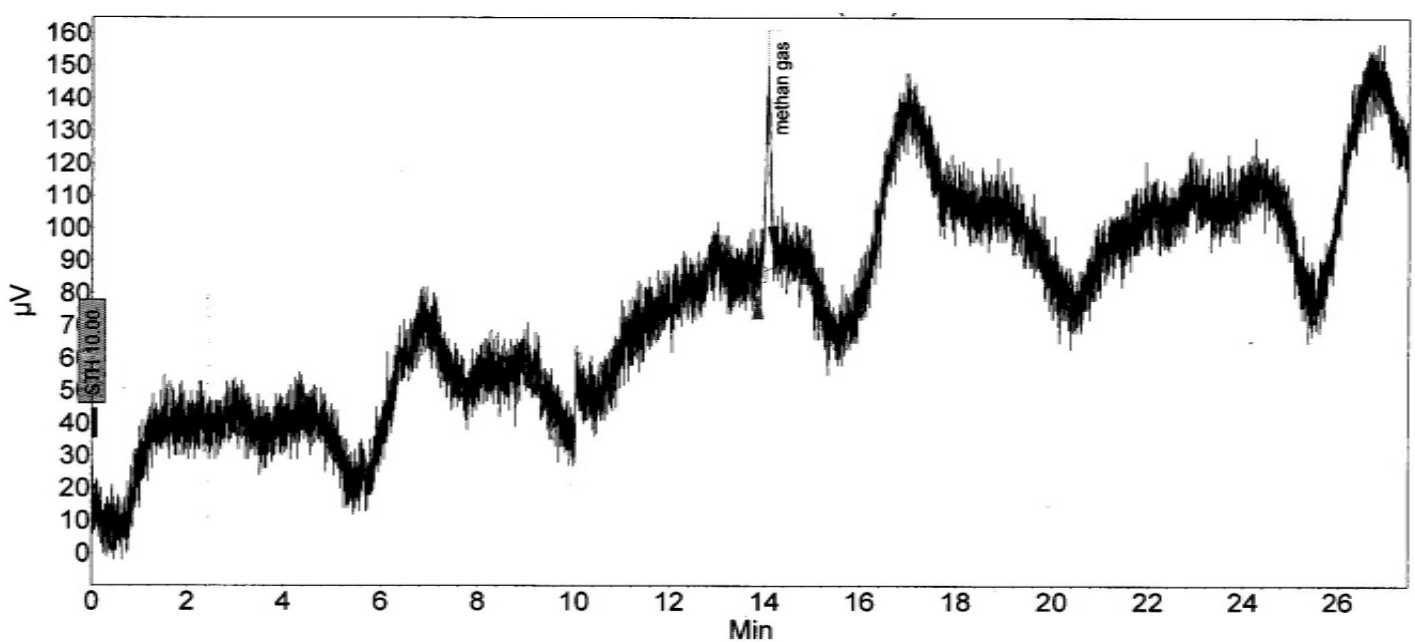

Fig. (5). Composite sample E for solid waste from site 3 and 4.

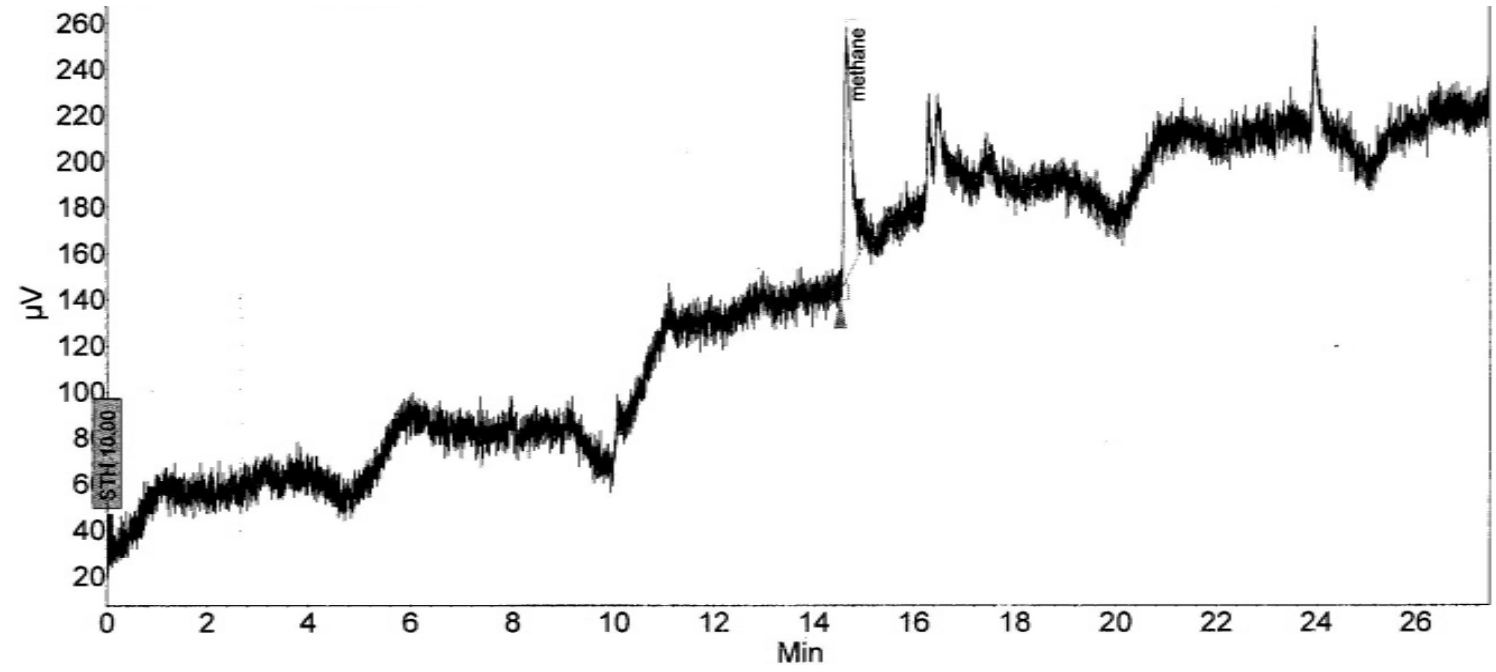

Fig. (6). Composite sample F for solid waste from site 3 and 4. 


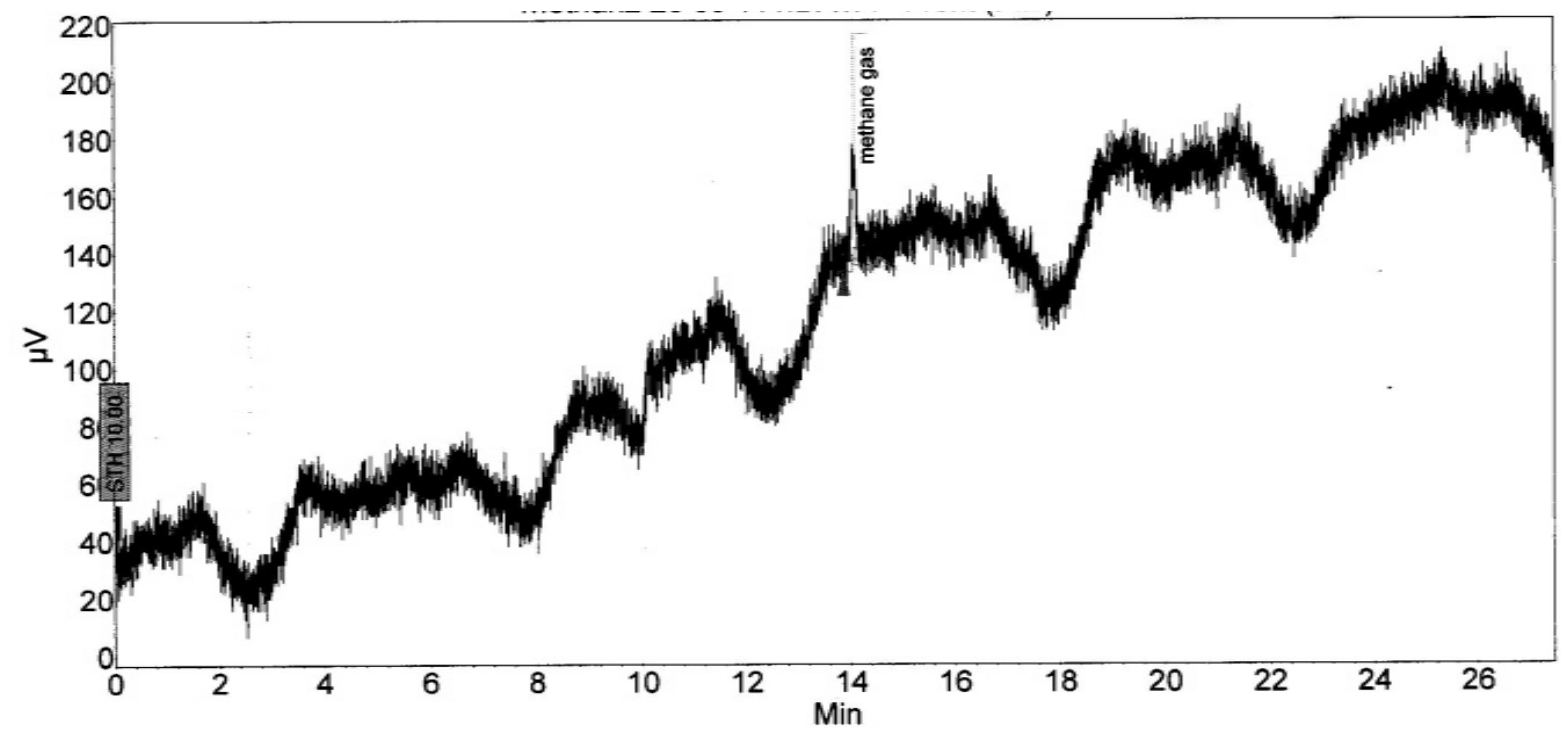

Fig. (7). Composite sample $\mathrm{G}$ for solid waste from site 3 and 4.

the organic material, such as paper, food, yard wastes, and animal and plant waste, available to sustain methane producing microorganisms. The methane production capacity is proportional to the quantity of the organic material. Methane generation continues as long as the site continues to receive waste and declines after the site stops to receive the waste. In addition, the methane generating bacteria need nitrogen, phosphorous, sulphur, potassium, sodium and calcium for cell growth. These nutrients are abundant and primarily derived from the organic waste. It also contains moisture, some of which comes from incoming waste, water produced by decomposition, sludge, precipitation, surface and ground water infiltration. Moisture is essential for anaerobic decomposition, cell growth, the life of the methanogenic archae and their metabolic reactions. Water serves as a transport medium for the nutrients, bacteria and alkaline substances within the refuse. As the moisture level increases the bacteria become more active and multiply, and increase methane production. At warm temperatures, the rate of methanogenic archae growth is related to the amount of degradable organic carbon that will generate methane and other landfill gases. At temperatures below $10-15^{\circ} \mathrm{C}$, methane production is drastically reduced. Because the majority of the methane production occurs in the deeper layers of the disposal sites, where heat is generated from anaerobic decomposition, temperatures typically range between $25-40^{\circ} \mathrm{C}$. An average of $35^{\circ} \mathrm{C}$ can be expected within the anaerobic zone (below 6.5-13 feet). The temperature of waste in the disposal site depends on the depth, the number of layers covering the site and the climate. Furthermore, methane is produced in a neutral environment, close to $\mathrm{pH} 7$. The optimal $\mathrm{pH}$ for gas production is near neutral, between 6.8 and 7.2. Methane generation is prohibited by acidic environment $(<6.0)$. Alkaline substance dissolved in water help to balance the $\mathrm{pH}$ level and neutralize the organic acids, which in large concentrations decrease methane production. Leachate $\mathrm{pH}$ and nutrient availability go hand in hand. The values of $\mathrm{pH}$ vary with the depth of filling, indicator of aerobic or anaerobic reactions [9]. Figs. (5, 6 and 7) are the chromatogram peaks generated for the samples collected from sites where frequent burning of the solid wastes was done and were shorter as compared to (Figs. 2, 3 and 4).

These showed that low amounts of methane were generated from these samples which contained less organic material. Methane gas emissions reduce drastically after burning and combustion leads to the generation inorganic matter. The dry inorganic matter has little or no moisture, less organic matter and readily available nutrients. During burning, at extremely high temperatures (above $60^{\circ} \mathrm{C}$ ) methane generation ceases due to reduction or no bacterial growth and activity since some or all of the microorganisms are killed. Furthermore, the degradable organic carbon (DOC) in the waste which can be metabolized by the methanogenic archae to produce methane gas is reduced hence low amounts of methane gas are generated. The difference between the two sets of results for the waste from organic and inorganic sources respectively showed that the method can qualitatively give a measure of the amount of methane gas in solid waste depending on the amounts of organic matter available.

\section{CONCLUSIONS}

Based on these results, the more the organic matter the higher the methane gas produced; hence the solid waste from sites 1 and 2 is a better source for the methane gas. Further development of measurement techniques especially focusing on cost reduction is required in Uganda. The GC-FID method for the qualitative methane gas estimation could be used as an initial assessment tool before quantification by another method is carried out. More research and data is required to validate and hence ascertain future use of the method. The fact that Uganda is an agricultural based country and so far compositing seems new to the public there is a high chance that if promoted it can be one of way to avail cheap energy sources to communities as we save our environment too. The method can be use to make qualitative evaluation of solid material to produce especially biogas which can be used as energy, and also use of the waste as fertilizer. These applications to will ensure sustainability of the environment and agriculture in Uganda. 


\section{CONFLICT OF INTEREST}

None declared.

\section{ACKNOWLEDGEMENT}

The authors are very grateful to Inter-University Council of Eastern Africa through Lake Victoria Research (VicRes) for accepting to pay for the publication of this work. We also acknowledge the guidance and support by Dr. E. N. Lutalo, District Support Officer, National Environment Management Authority, Kampala-Uganda and J. Iberet, Analytical Chemist at the Uganda National Bureau of Standards, KampalaUganda.

\section{ACRONYMS}

GC-FID $=$ Gas chromatography with a Flame Ionization Detector

GC $=$ Gas chromatography

DOC $=$ Degradable organic carbon

FID $=$ Flame Ionization Detector

$\mathrm{KCCA}=$ Kampala City Council Authority

WS $\quad=$ Solid Waste

MSW = Municipal Solid Waste

\section{REFERENCES}

[1] UBOS, (Uganda National Bureau of Statistics), "Preliminary Results for Uganda Population and Housing Census", 2009.

[2] A. Robinson, G. Sewell, N. Damodaran, E. David, and N. KalasAdams, "Landfills in developing countries and global warming", Proceedings Sardinia, Ninth International Waste Management and Landfill Symposium S. Margherita di Pula, Cagliari, Italy. CISA, Environmental Sanitary Engineering Centre, 2003.

[3] S. Kumar., S.A., Gaikwad, A.V. Shekdar, P.S. Kshirsagar and R.N. Singh, "Estimation method for national methane emission from solid waste landfills", Atmos. Environ., vol. 38, pp. 3481-3487, 2004a

[4] NEMA, (National Environment Management Authority), "The State of the Environment Report for Uganda", Kampala-Uganda, 2007/2008

[5] H. Scharff and J. Jacobs, "Applying guidance for methane emission estimation for landfills", Waste Manag., vol. 26, pp. 417-429, 2006

[6] M. Meadows, "Proceedings of the International Energy Agency Greenhouse Gases: Mitigation Options Conference", Energy Convers. Manag.,. vol. 37, pp. 1099-1104, 1996

[7] D.H. Kampbell and S.A. Vandegrift, "Analysis of dissolved methane, ethane, and ethylene in ground water by a standard gas chromatographic technique", J Chromatogr. Sci.,. vol. 36, pp. 253-256, 1998

[8] U.S. EPA (U.S. Environmental Protection Agency), "A Guide to Landfill Gas Recovery and Use Projects at Landfills and Open Dumps". Draft report, December 4, 2001

[9] S. Kumar, A.N. Mondal, S.A. Gaikwad, S. Devotta, and R.N. Singh, "Qualitative assessment of methane emission inventory from municipal solid waste disposal sites: a case study", Atmos. Environ., vol. 38, pp. 4921-4929, 2004.

(C) Nakibuuka et al.; Licensee Bentham Open.

This is an open access article licensed under the terms of the Creative Commons Attribution Non-Commercial License (http://creativecommons.org/licenses/by-nc/3.0/g) which permits unrestricted, non-commercial use, distribution and reproduction in any medium, provided the work is properly cited. 